\begin{tabular}{|c|c|}
\hline \multirow{3}{*}{ 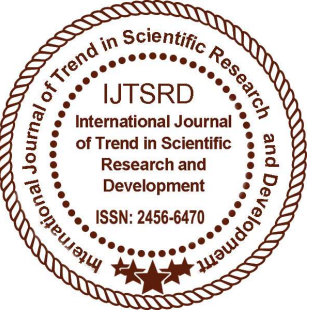 } & $\begin{array}{l}\text { International Journal of Trend in Scientific } \\
\text { Research and Development (IJTSRD) }\end{array}$ \\
\hline & International Open Access Journal \\
\hline & ISSN No: 2456 - 6470 | www.ijtsrd.com | Volume - 1 | Issue - 6 \\
\hline
\end{tabular}

\title{
Impact of Residential Relocation on Livelihood of Slum Dwellers - A Case Study of Three Slums in Khammam Municipal Corporation
}

\author{
Shweta Sharma \\ Assistant Professor, Department of Planning, \\ School of Planning and Architecture, Vijayawada
}

\author{
Thokala Leeyana Mouni \\ Department of Planning, \\ School of Planning and Architecture, Vijayawada
}

\begin{abstract}
Andhra Pradesh is the second most slum populated state in the country as per Census 2011. It accounts for 34.4 percent of slum population to the total slum population of the country. Most of the slum dwellers live in unhygienic conditions with lack of basic facilities such as toilets, drainage etc. The study aims to develop the conceptual framework for enhancing livelihood of slum dwellers through enhancing capabilities and functions. The chosen study area is Khammam Municipal Corporation where 13 slums have been relocated to 3 different slums outside the city.
\end{abstract}

Keywords: Khammam, livelihood, slum, capability, function, relocation

\section{INTRODUCTION}

Developing countries have mostly suffered from problems of urbanization where India is considered as one of them. Growth of urbanization leads to increase in slums in urban areas. For urban poor slums are considered as easily accessible and affordable. The increase in rural urban migration has the main reason for the slums rapid increase. In India the percentage of urbanization is significantly increased from 10.8 percent in 1901 to 31.2 percent in 2011. Andhra Pradesh contributes 34.4 percent of slum population to the total slum population of Indian cities. 35.7 percent of the urban households are slum dwellers in the state. Slums in the urban areas are increasing everyday because they are the only place that is easily accessible for the rural and urban migrants to stay.
Governments, Non-Government Organization (NGO) etc. have attempted to relocate and redevelop the slums thereby lessoning their vulnerable situation. However, relocation has created more problems than earlier due to lack of involvement of slum dwellers in decision-making process.

\section{Objectives and Methodology}

The research was undertaken keeping certain objectives in mind which were as follows:

i. To analyze the link between livelihood activities of slum dwellers in relation to capabilities and location

ii. To analyze the link between livelihood activities of slum dwellers in relation to functions and location

iii. To analyze the land-use change of slums pre and post relocation

The study included different stages of which the stage one was the literature review. The literature study was divided into different themes. The first theme was to understand the definition of Livelihood, Slum, Relocation and Resettlement. Second theme was the conceptual understanding of various related theories related to livelihood. Third theme was to understand the theoretical understanding in terms of various urban poverty alleviation programmes and schemes. Fourth theme was to study policies related to skill development, vulnerability and poverty that have been 
adopted in India. Finally, fifth theme was case study specific where different case studies were refereed to understand the situation before going to field visit. After the literature review was carried out from five different themes, the parameters were identified. Based on the parameters the questionnaire was prepared and data was collected from both primary and secondary sources at the time of field visit.

\section{Study area: Khammam}

Khammam has been chosen as the care to conduct this research. It was a deliberate decision to choose Khammam as already of couple of studies have been done on metropolitan areas with population more than 100,000 areas but not in urban centers with population between 100,000 to 999,999 . Khammam city is in Khammam District of Telangana state and, it is the headquarters of the district. The City is located on the banks of a river called Munneru, which is a tributary of the Krishna River. In 2012 it was announced as a Municipal Corporation. The municipal corporation is spread over $93 \mathrm{sq}$. $\mathrm{km}$. with a population of 3,56,000. The population of the city is increasing manifold due to constant migration of people from rural areas who do not get housing in the city and thus contribute to the slum population. Around 28.82 percent of people reside in slum's i.e. 72,664. There are 71 slums (notified 28 and non notified 43) in Khammam municipality. When Khammam was declared as Municipal Corporation in 2012, the municipal corporation chose 13 slums to be relocated to three different slums in sub-urban areas (Figure 1) namely Indiramma Colony, Y.S.R Colony and K.C.R Colony (figure 2).

\section{Data}

The collected data can be divided into two types: primary data and secondary data. Primary data was collected by through primary survey. Secondary data is second hand data that was collected by some other surveyor for some other (or for his own) purpose. Several methods were used to carry out primary survey that includes survey through questionnaire, focus group discussion and personal interview. Questions were framed based on exiting literature. The parameters to prove the hypothesis have been derived from the Capabilities approach given by Amartya Sen. Individuals differ greatly in their abilities to convert the same resources into valuable functionings ('beings' and 'doings'). To realize those functionings (such as their genuine opportunities to be educated, their ability to move around or to enjoy supportive social relationships) what is required are capabilities in terms of subjective things (such as happiness, satisfactory levels etc.) and on material means to well being (such as resources like income or wealth). Capabilities in this research have been studied through skills, knowledge acquired by slum dwellers and multiple jobs available to them, proximity to school and proximity to hospital. The associated functionings to the capabilities have been measured through proximity and availability of jobs, proximity and availability of multiple opportunities, attending school and access to hospital.

Type of sampling considered for primary survey was Simple Random Sampling method in the study area. Cochran sampling technique, 1977 has been used to calculate sample size:

$$
\begin{aligned}
& X=\frac{t^{2} * P(1-P)}{M E^{2}} \text { Where, } \\
& \mathrm{X}=\text { number of samples, }
\end{aligned}
$$

$\mathrm{t}=$ Appropriate Value from the normal distribution for the desired confidence $95 \%$ i.e., 1.96 ,

$\mathrm{P}=$ Anticipated prevalence (Total population in one slum/ total slum population in Khammam Municipal Corporation),

$\mathrm{ME}^{2}=$ Marginal error (5\% margin of error i.e., 0.05$)$

The household survey, focus group discussion and face-to-face interview were conducted in the study area to collect the data relating to livelihood, capabilities and functions before and after relocation of slums.

\section{Analysis and discussion}

\subsection{Socio-Economic Profile}

There are more females than males in the slum, the distribution of gender is equal in KCR Colony and males are more than females in case of YSR Colony. In terms of education, more than $60 \%$ of the people are uneducated in Indiramma Colony KCR Colony, however less than $50 \%$ of people are uneducated in YSR Colony. The occupational suggests that while most of the men are engaged as auto drivers in Indramma Colony and YSR Colony, and females are housewives, KCR Colony on the other hand has a predominance of men engaged in construction activities and women being primarily housewives. 


\subsection{Comparative profile of slums pre and post relocation}

\subsubsection{Income Levels}

The income levels have decreased post relocation of slums in all the three slums. More people have come within the income bracket of ₹ $1000-₹ 3000$ per month, which happens to be the lowest income bracket.

\section{Cost of travel:}

Similarly cost of travel to work, school and hospitals increased substantially post relocation. In case of travel to work and school, the costs have doubled for an average being spent as $₹ 20$ per day pre-relocation to ₹ 60 per day being spent post relocation. With regard to medical facilities, the travel cost has gone beyond ₹ 100 per visit, while it was ₹ 40 per month on average pre relocation.

\subsubsection{Distance to work:}

The increasing cost of travel is a direct result of increased distance to schools, hospitals and places of work. The average distance to work for the males has increased from 2-5 Km pre-relocation to more than 8 $\mathrm{Km}$ post relocation. For females, distance to work has decreased from 7-8 $\mathrm{Km}$ to 5-6 $\mathrm{Km}$ because they used to work as agricultural labors earlier but need to go to far off places now to work as maids (figure 3,4 ).

\subsubsection{Distance to hospital and school}

Proximity to hospital and schools is considered as capability. Distance to facilities has increased per trip and cost per trip has also increased which are considered as functions. Because of the increase in distance and cost of travel to schools and hospitals (Figure 5,6,7,8), functions to school and hospitals decreased. According to URDPFI guidelines, distance of facilities to residential location of slum dwellers is should be maximum $4 \mathrm{Km}$ for Hospital and $0.5-1 \mathrm{Km}$ for schools. Before relocation facilities were accessible as per standards, however, after relocation facilities are not in proximity. Proximity to school and hospitals is important because it will help in increasing the capabilities, which will lead to functions, as a result this will lead to better livelihood prospects.

\subsection{Regression Analysis}

A regression analysis was done to ascertain how the parameters are related to income in case of the three slums. The formula for regression was as follows:
Income $=$ intercept + coefficient $* d t w+$ coefficient $*$ ctw + coefficient $* d s+$ coefficient $*$ cts + coefficient $* d h+$ coefficient $*$ cth

where:

$\mathrm{ctw}=$ cost of distance to work;

cts $=$ cost of travel to school;

$\mathrm{cth}=$ cost of distance to hospital

Here income is the dependent variable and remaining all parameters are independent variables affecting income.

\subsubsection{Regression: Indiramma Colony}

The regression equation for Indiramma colony is as follows:

\section{Income $=2.94-0.02$ ctw -0.08 cts -0.07 cth}

The equation reveals a major impact of cost of travel to school on the income levels of residents in Indiramma colony. Pre-relocation, $69 \%$ of slum dwellers were spending no money on sending their children to schools as the schools were within walking range of $0.5-1 \mathrm{~km}$. However, post relocation the distance to school increased to $5 \mathrm{kms}$ and thus $86 \%$ people are spending ₹ 40-50 per day to send their children to school. The interesting thing is the cost of travel to work does not have a strong bearing on income, as the residents have been able to find work opportunities near to their residential location postrelocation.

\subsubsection{Regression: KCR Colony}

The regression equation for KCR colony is as follows:

Income $=6.45-0.23 \mathrm{ctw}-0.23 \mathrm{cts}-0.41 \mathrm{cth}$

As per the regression analysis, the cost of travel to hospital has increased substantially and it has a major bearing on the income levels of residents in KCR Colony. While pre-relocation, $60 \%$ of slum dwellers used to spend between ₹40-50 per visit to the hospital, however, post-relocation the cost of travel per visit to the hospital increased to more than ₹ 100 .

\subsubsection{Regression: YSR Colony}

The regression equation for KCR colony is as follows:

\section{Income $=11.24-0.32$ ctw -0.08 cts -0.14 cth}

The cost of travel to work has a major impact on the income levels of residents of YSR colony. While the 
average cost of travel to work of the 13 re-located slums was ₹ 20 per day, the cost of travel has risen to ₹ $40-50$ for $60 \%$ of the residents of YSR colony. Similarly, cost of travel to hospital per visit has risen from ₹ 40 to ₹ 100 on average post relocation.

\subsection{Land Use Matrix}

The land use matrix analysis reveals the major land uses, pre and post relocation, in the 1.25 meter buffer. This 1.25 meter buffer is based on the average work distance proposed by the RAY scheme in India (figure $9,10)$. A variety of land uses provide multiple livelihood opportunities for residents. If land use composition is poor, then opportunities for slum dwellers will decrease and will lead to provision of a single job or no job. It was observed that postrelocation, the land use composition was low (table 1). Hence the relocation was negatively impacting the livelihood of slum dwellers.

\subsection{Cause and effect analysis}

The officials in Khammam Municipal Corporation are following top down approach without considering people's viewpoint while relocating the slums.

\section{Table 1: Land-use matrix}

\begin{tabular}{|l|l|l|l|l|l|l|l|}
\hline Slum Name & $\begin{array}{l}\text { Residen } \\
\text { tial }\end{array}$ & $\begin{array}{l}\text { Commer } \\
\text { cial }\end{array}$ & $\begin{array}{l}\text { Industri } \\
\text { al }\end{array}$ & $\begin{array}{l}\text { Publi } \\
\text { c/se } \\
\text { mi } \\
\text { publi } \\
\text { c }\end{array}$ & $\begin{array}{l}\text { Gree } \\
\text { cover }\end{array}$ & $\begin{array}{l}\text { Agri } \\
\text { cultu } \\
\text { ral }\end{array}$ & $\begin{array}{l}\text { Fore } \\
\text { st } \\
\text { land }\end{array}$ \\
\hline Sweepers Colony & Yes & Yes & No & Yes & No & No & No \\
\hline Pakabanda Dhobhiwada & Yes & Yes & No & Yes & Yes & No & No \\
\hline Shukravaripeta & Yes & Yes & Yes & Yes & Yes & No & No \\
\hline Nizampet & Yes & Yes & No & Yes & Yes & No & No \\
\hline Ricob Bazar & Yes & Yes & No & Yes & & No & No \\
\hline Parsibandam & Yes & No & No & Yes & Yes & No & No \\
\hline Sambhani Nagar & Yes & No & No & Yes & Yes & No & No \\
\hline Srinivas Nagar & Yes & No & Yes & Yes & Yes & No & No \\
\hline Labadi Thanda & Yes & Yes & Yes & Yes & Yes & No & No \\
\hline sharada nagar & Yes & Yes & No & Yes & Yes & No & No \\
\hline Ramana Gutta & Yes & Yes & No & Yes & Yes & No & No \\
\hline S.T. Colony & Yes & Yes & Yes & Yes & Yes & No & No \\
\hline S.C. Colony & Yes & Yes & Yes & Yes & Yes & No & No \\
\hline Indiramma Colony & Yes & No & No & No & No & Yes & Yes \\
\hline Y.S.R Colony & Yes & No & No & No & No & Yes & Yes \\
\hline K.C.R Colony & Yes & No & No & No & No & Yes & Yes \\
\hline
\end{tabular}


The rural people are migrating from rural to urban areas, in search of better livelihood. This is leading to rapid increase of slums in urban areas. As a result, relocation of slums is happening in urban areas, which is affecting their capabilities and functions and finally impacting their livelihood negatively. The cause and effect of this cyclical proves is explained in figure 11. The major issues in the relocation process done for slums in Khammam city are that the land from where the slums have been relocated is being used for commercialization instead of using for low income housing, the new land has not benefitted the poor, current framework does not respond to economic issues, capabilities (opportunities) and functions (performing opportunities) have decreased and the residents of the three relocated colonies have not received any payment as promised by government officials (table 2).

Table 2: Average income and expenditure per month

\begin{tabular}{|c|c|c|c|c|c|c|c|c|c|}
\hline $\begin{array}{l}\text { Relocated } \\
\text { colony } \\
\text { name }\end{array}$ & $\begin{array}{l}\text { Reloc } \\
\text { ation } \\
\text { status }\end{array}$ & $\begin{array}{l}\text { Income } \\
\text { (Rs.) }\end{array}$ & $\begin{array}{l}\text { Cost of } \\
\text { travel } \\
\text { to work } \\
\text { (Rs.) }\end{array}$ & $\%$ & $\begin{array}{l}\text { Cost of } \\
\text { travel } \\
\text { to } \\
\text { school } \\
\text { (Rs.) }\end{array}$ & $\%$ & $\begin{array}{l}\text { Cost of } \\
\text { travel to } \\
\text { hospital } \\
\text { (Rs.) }\end{array}$ & $\%$ & $\begin{array}{l}\text { Total } \\
\text { Cost of } \\
\text { travel } \\
\%\end{array}$ \\
\hline \multirow{2}{*}{$\begin{array}{l}\text { Indiramma } \\
\text { colony }\end{array}$} & Pre & 5319.6 & 134 & 2.5 & 170 & 3.19 & 38.86 & 0.73 & 6.42 \\
\hline & Post & 4523.5 & 1368 & 30.24 & 664.56 & 14.69 & 80 & 1.76 & 46.69 \\
\hline \multirow{2}{*}{$\begin{array}{l}\text { 2.K.C.R } \\
\text { Colony }\end{array}$} & Pre & 7251.5 & 729 & 10.05 & 360 & 4.96 & 34.75 & 0.47 & 15.48 \\
\hline & Post & 6964 & 1774.8 & 25.48 & 601.9 & 8.64 & 99 & 1.42 & 35.54 \\
\hline \multirow{2}{*}{$\begin{array}{l}\text { 3. Y.S.R } \\
\text { Colony }\end{array}$} & Pre & 8659.1 & 453 & 5.23 & 258 & 2.97 & 40.91 & 0.47 & 8.67 \\
\hline & Post & 7859.1 & 1698 & 21.6 & 731.64 & 9.30 & 100 & 1.27 & 32.17 \\
\hline
\end{tabular}

\section{Conclusion}

In Khammam City, the relocation of slums did not happen according to standards. 13 slums were relocated to three different areas, which are all in the peripheral areas of the city. The various analysis conducted during the research revealed that the relocation is negatively impacting capabilities and functions, which negatively impacts the livelihood of the slum dwellers.

This is perhaps due to the top-down approach followed by Municipal Corporation during relocation. The people migrated to cities for better livelihood but again they were relocated to sub-urban areas that are vulnerable in terms of provision of various facilities and opportunities for the residents of the relocated colonies. Thus it is strongly recommended that the future relocation exercises for slums in urban areas should be essentially bottom-up where all the bodies and agencies (government and non- government) and private sector should coordinate and give the proposals based on the survey and view points of people to build a better society. Due to time constraints, the study was only limited to the slums relocated over the last two years. However, if a similar research would be conducted for slums relocated for a longer duration, then it would generate interesting results. Also, as a matter of convenience, only notified slums were considered for research. However, future research can also concentrate on nonnotified slums as well. This research paves a way for future work to be done in context of understanding impact on capabilities and functions of slum dwellers rather than simply looking at their income and expenditure patterns in the process of relocation.

\section{References}

1) Abu-Salia R, Kanton Osumanu I and Abubakari Ahmed. (2015). Coping with the Challenges of Urbanization in Low Income Areas: An Analysis of the Livelihood Systems of Slum Dwellers of the 
Wa Municipality, Ghana. Ghana: Scientific research publishing.

2) Alamgir M. S, Jabbar M. A and Islam M. S. (2009) Assessing the livelihood of slum dwellers in Dhaka city, Journal of Bangladesh Agriculture University. 7(2): pp. $373-380$.

3) Beall J and Nazneen Kanji1, (March 1999) Households, livelihoods and urban poverty. Department of Social Policy and Administration London School of Economics and Political Science. London.

4) Chambers, C. (1992). The Sustainable Livelihood Approach to Poverty Reduction. Swedish international development cooperation agency. Sweden: Sida.

5) Chattopadhyay.S, Biswas.A. (2010). Slum improvement through legal framework in India, International Journal for Housing Science, Vol.34, No.2 pp. 139-150.

6) Government of India. (2013). Best Practices: Habitat Planning \& Design for the Urban Poor. Delhi: Ministry of Housing \& Urban Poverty Alleviation.

7) Government of India. (2013). National Urban Livelihood Mission. Delhi: Ministry of Housing \& Urban Poverty Alleviation.

8) Government of India. (2011). Rajiv Awas Yojana. Delhi: Ministry of Housing \& Urban Poverty Alleviation.
9) Government of India. (2013). State of slums in India: A statistical compendium. Delhi: Ministry of housing and urban poverty alleviation, National building organisation.

10) Johannesburg, J. (2014). Forced relocation from informal settlements to the periphery and effects on livelihoods: A case of Diepsloot, South Africa. International Journal of Urban and Regional Research, Vol. 27(3), pp. 591-612.

11) Patil, R. 2012. The Civic Facilities: A Study of Resettlement in Kagal Taluka of Kolhapur District. Golden Research Thoughts, Vol. 1 (IX) pp. 1-4.

12) Sen, A. (1981). Poverty and Famines - As Essay on Entitlement and Deprivation. Oxford: Clarendon press.

13) Uancharoenkul P (2009) A Slum Upgrading Framework Taking Opportunity Cost into Account: A case study of Thailand. Dept. of Real Estate and Construction Management Master of Science, Thesis no. 466, Div. of Building and Real Estate Economics. Thailand.

14) UK Department for International Development. (1997). Sustainable Livelihoods Guidance. Department for international development. United Kingdom 
Figure 1: Slum Map of khammam

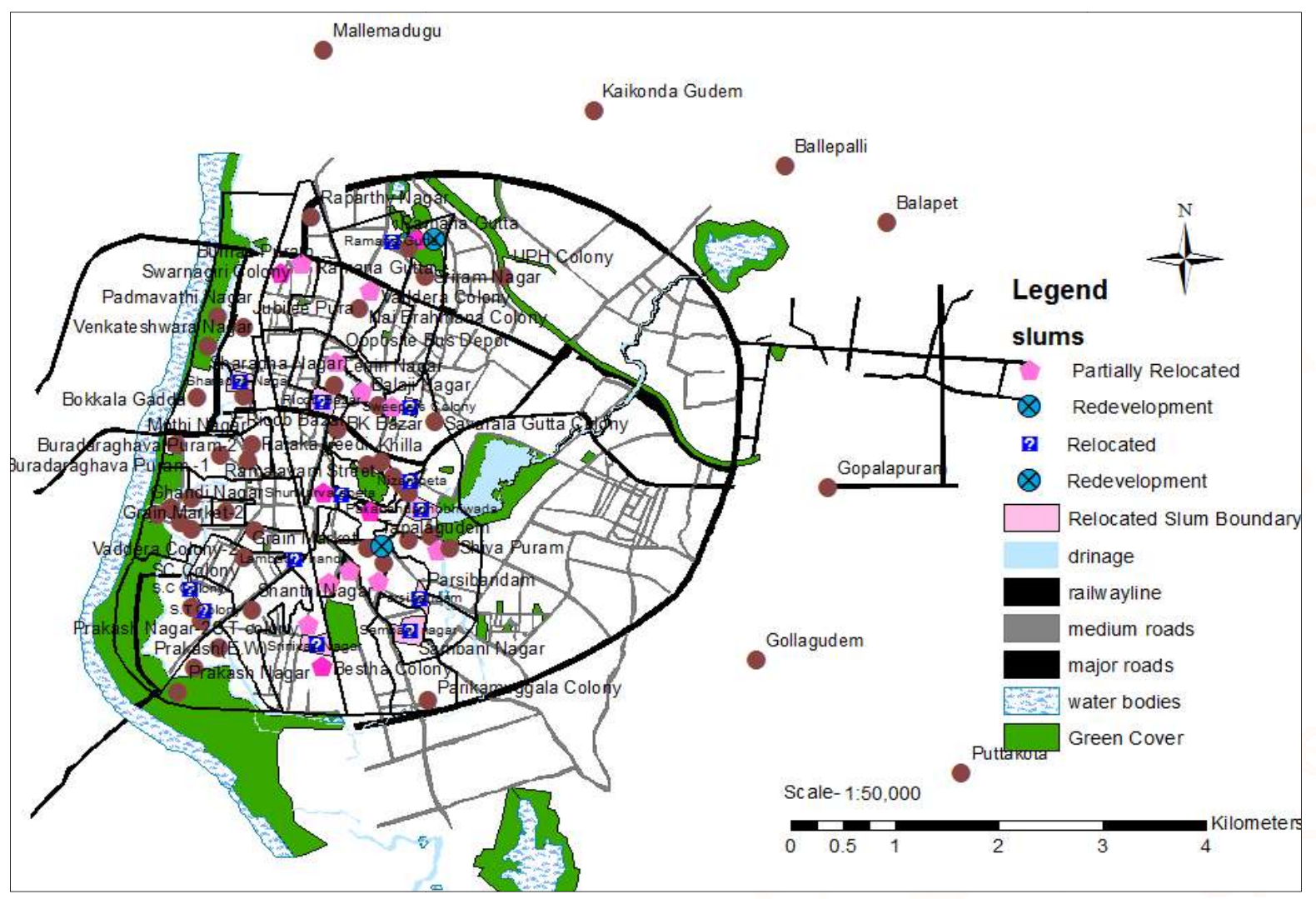

Figure 2: Three relocated slums

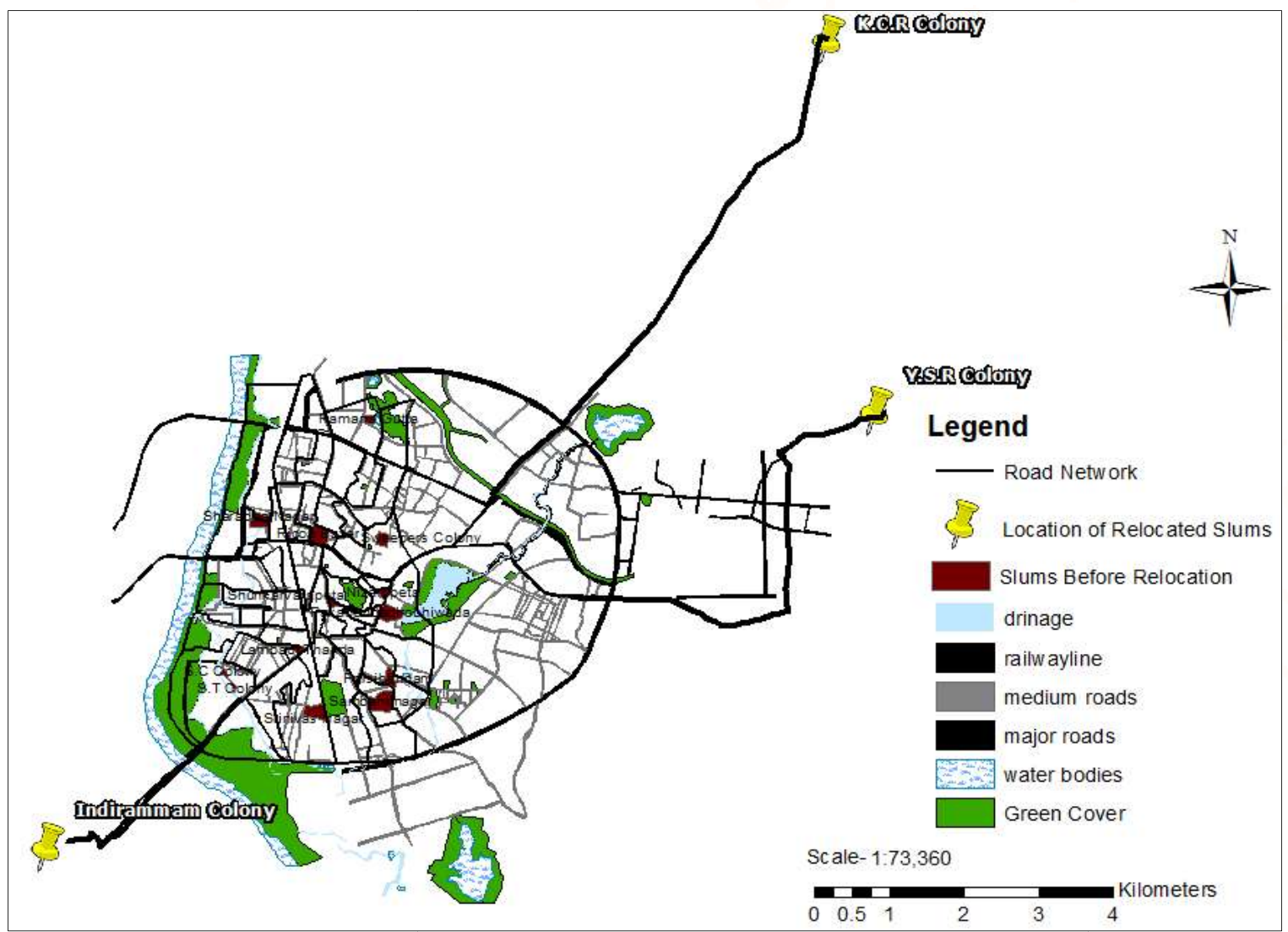




\section{Figure 3: Distance to work pre-relocation}

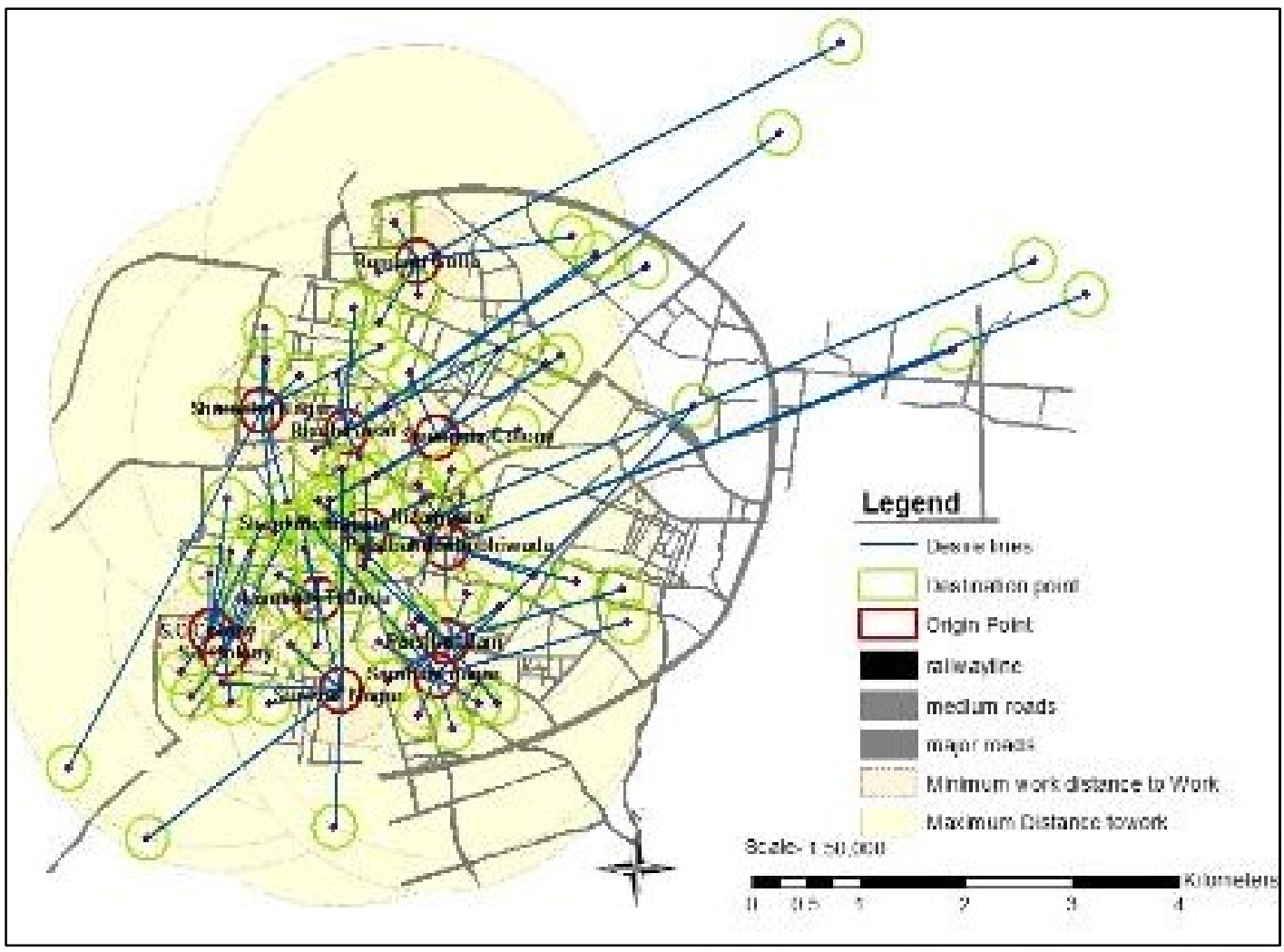

Figure 4: Distance to work post-relocation

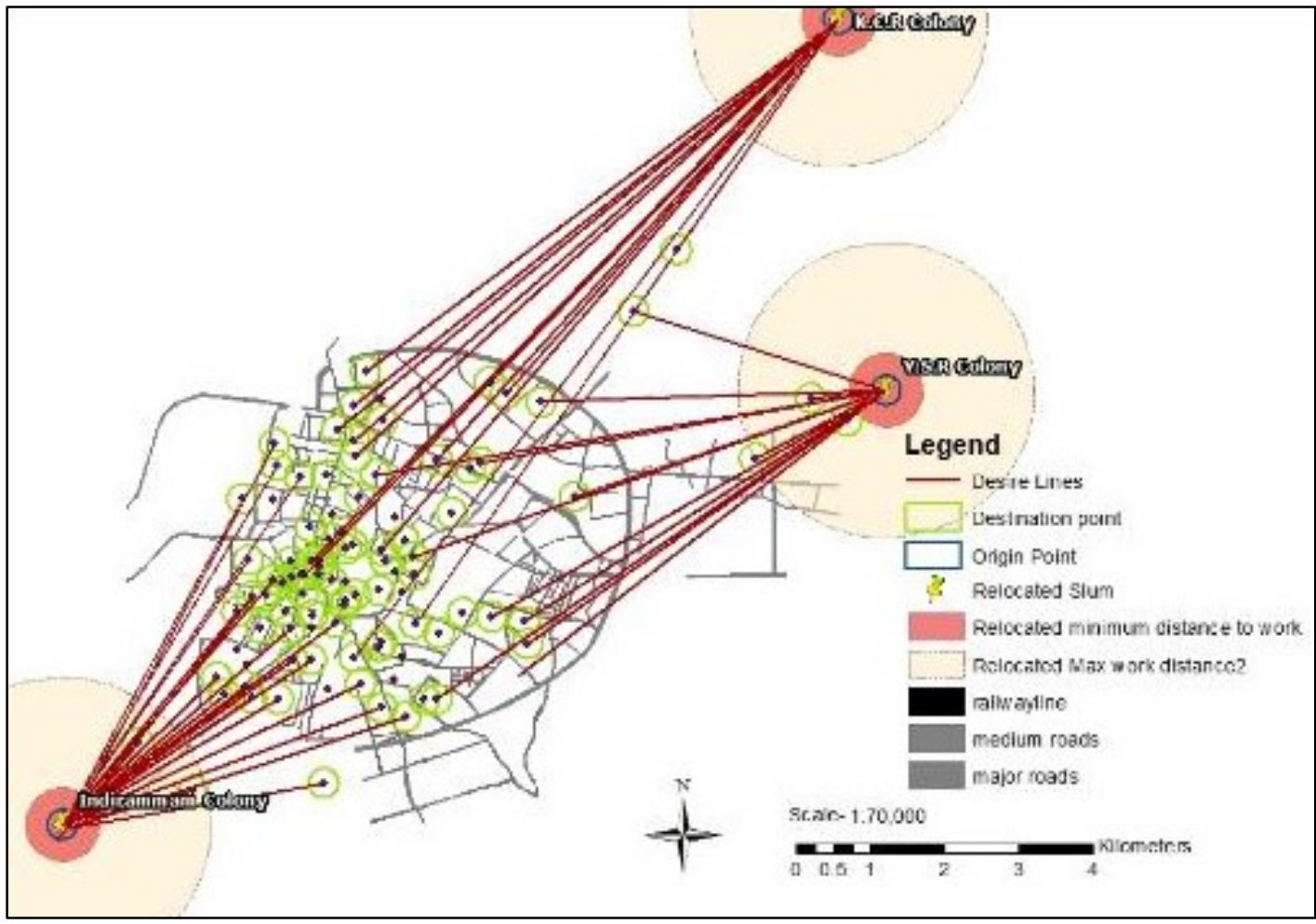


Figure 5: Distance to hospital pre-relocation

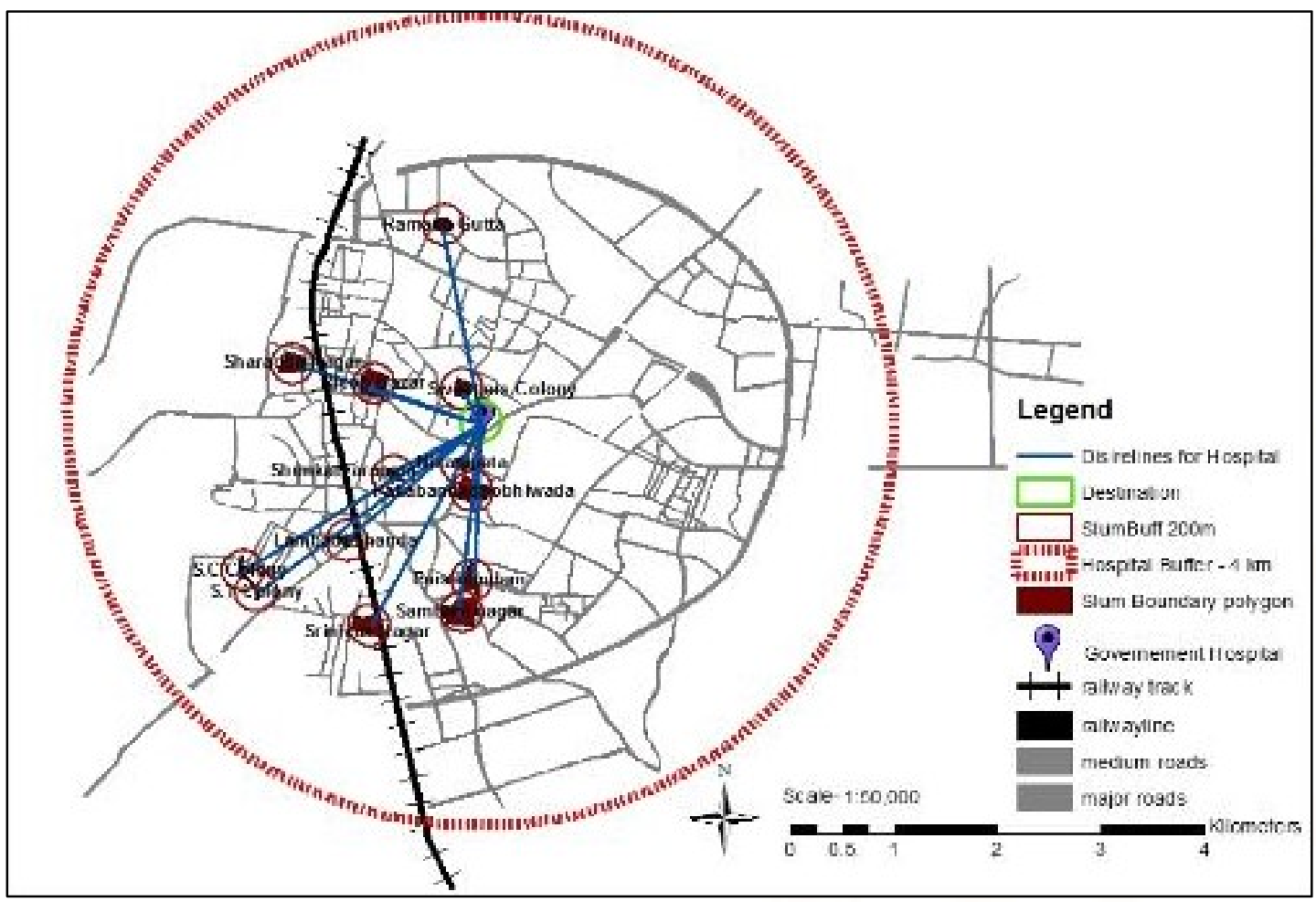

Figure 6: Distance to hospital post-relocation

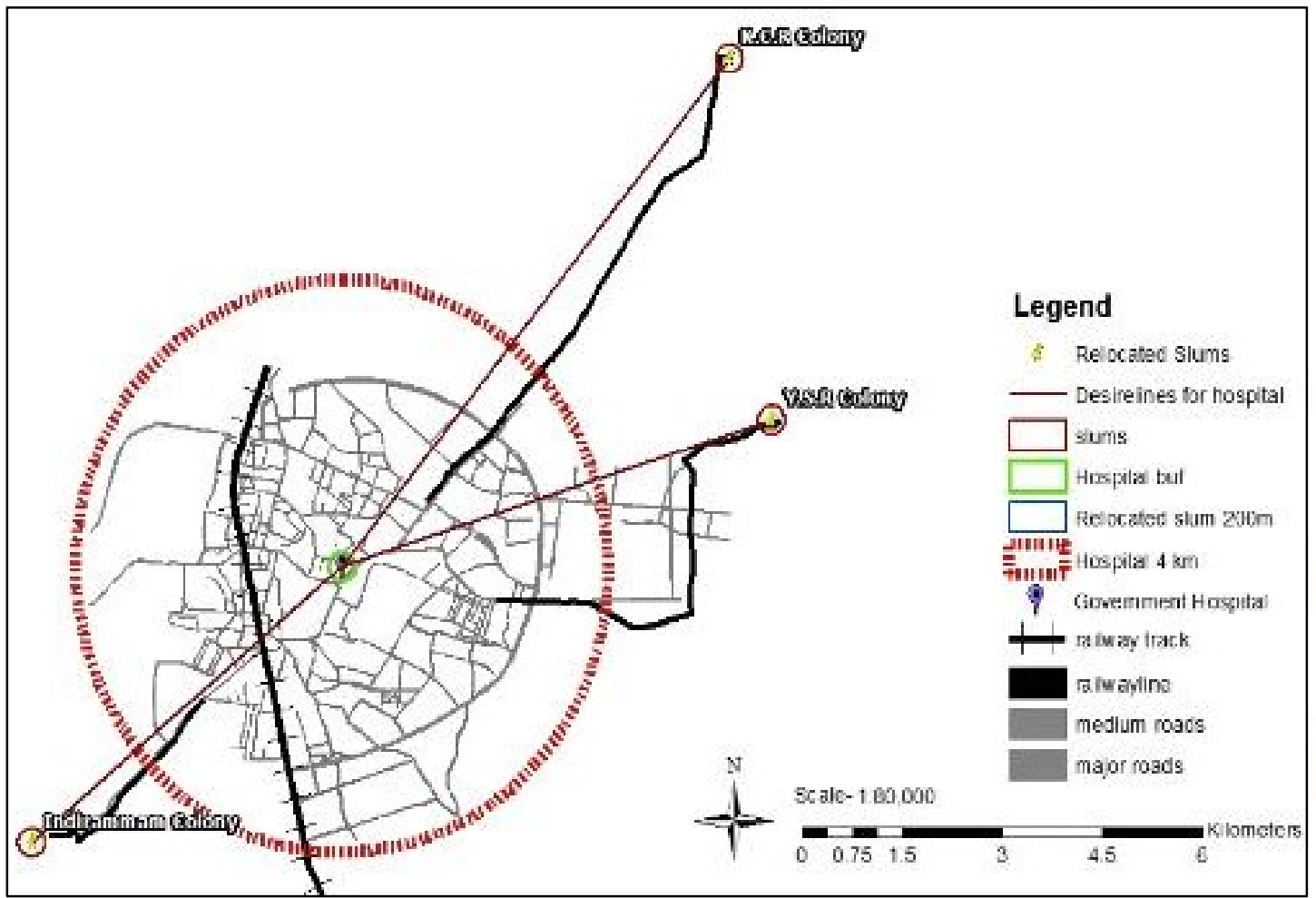


Figure 7: Distance to schools pre-relocation

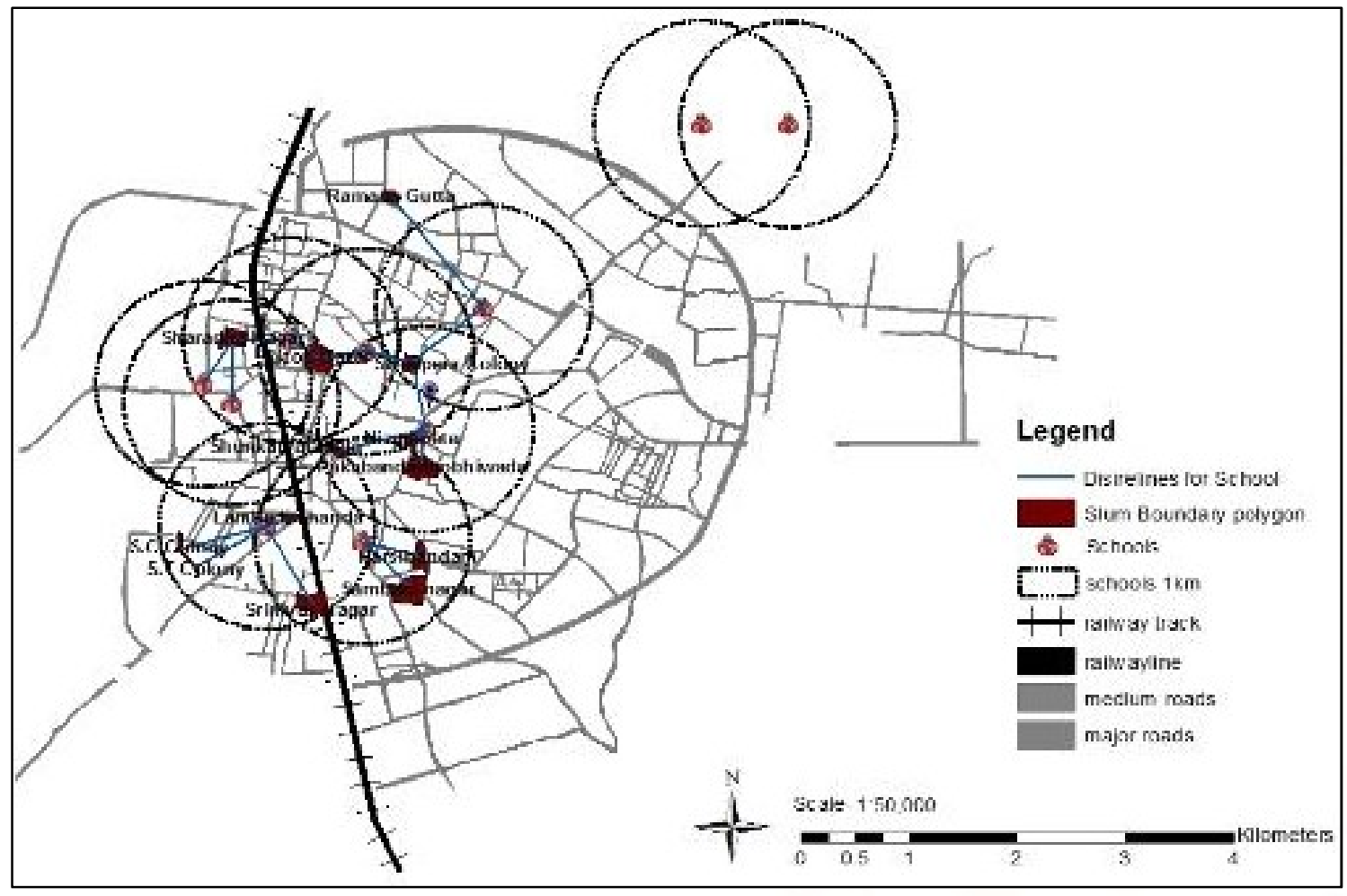

Figure 8: Distance to schools post-relocation

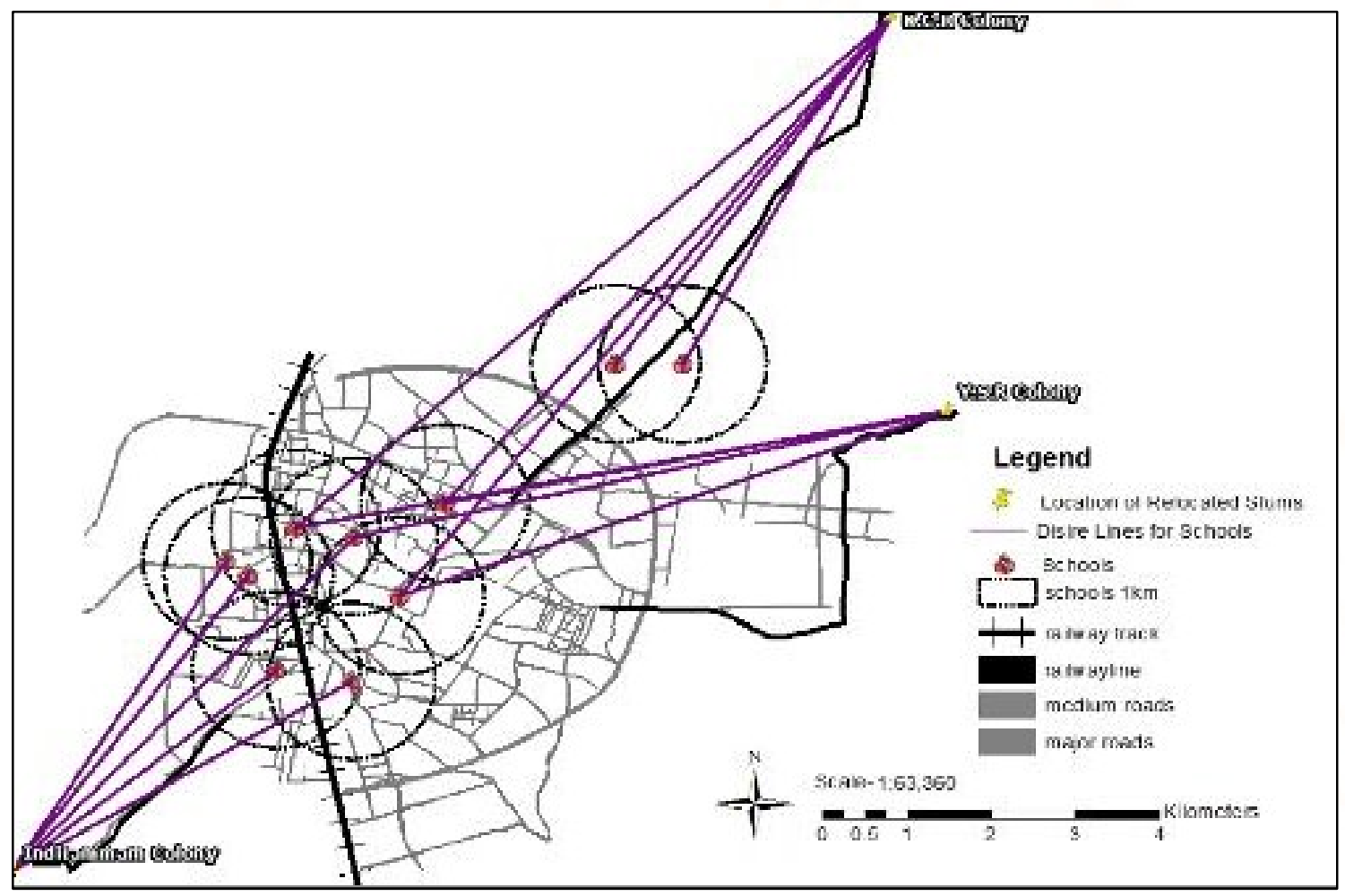


Figure 9: Land Use pre-relocation

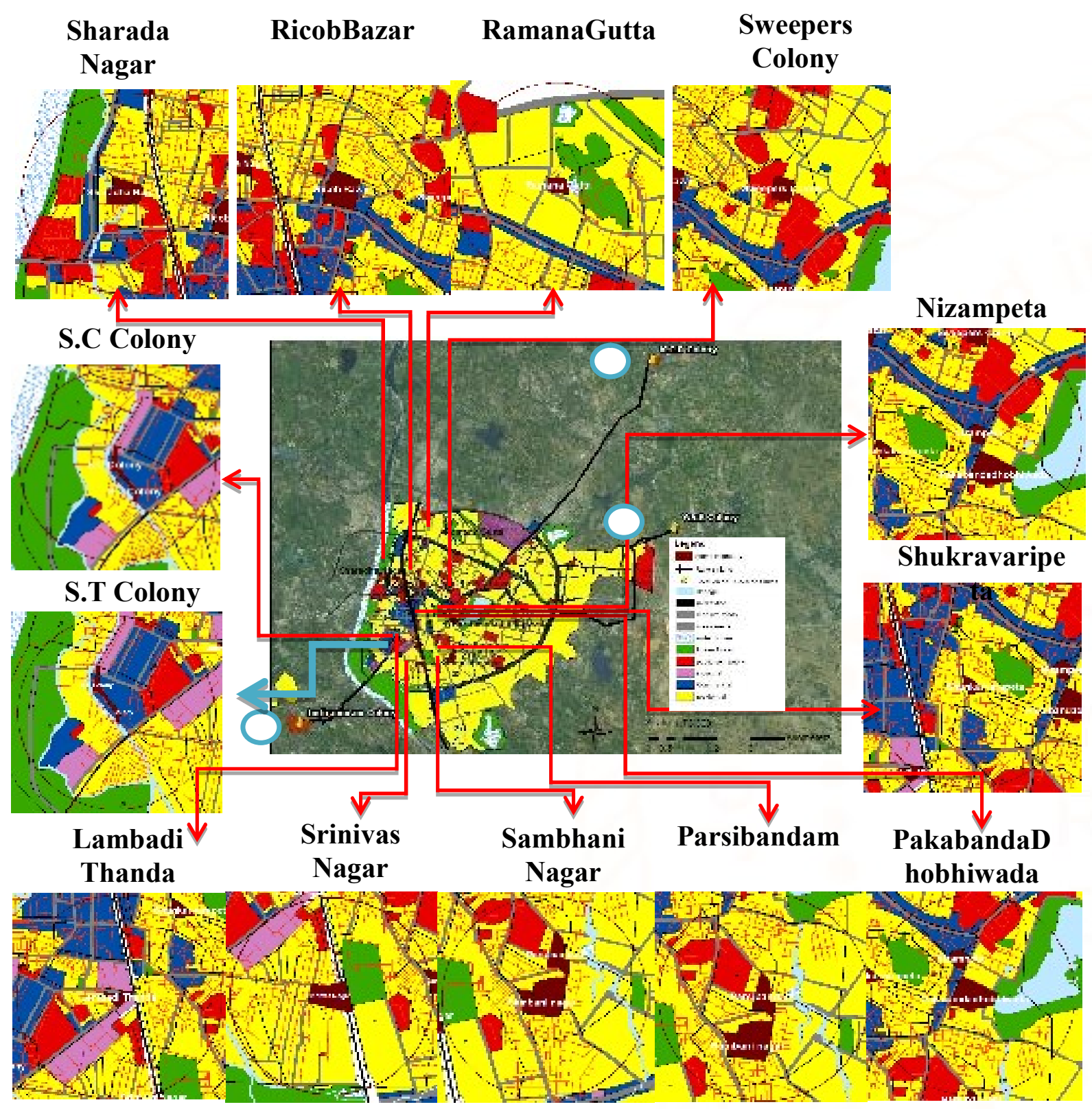

Figure 10: Land Use post-relocation

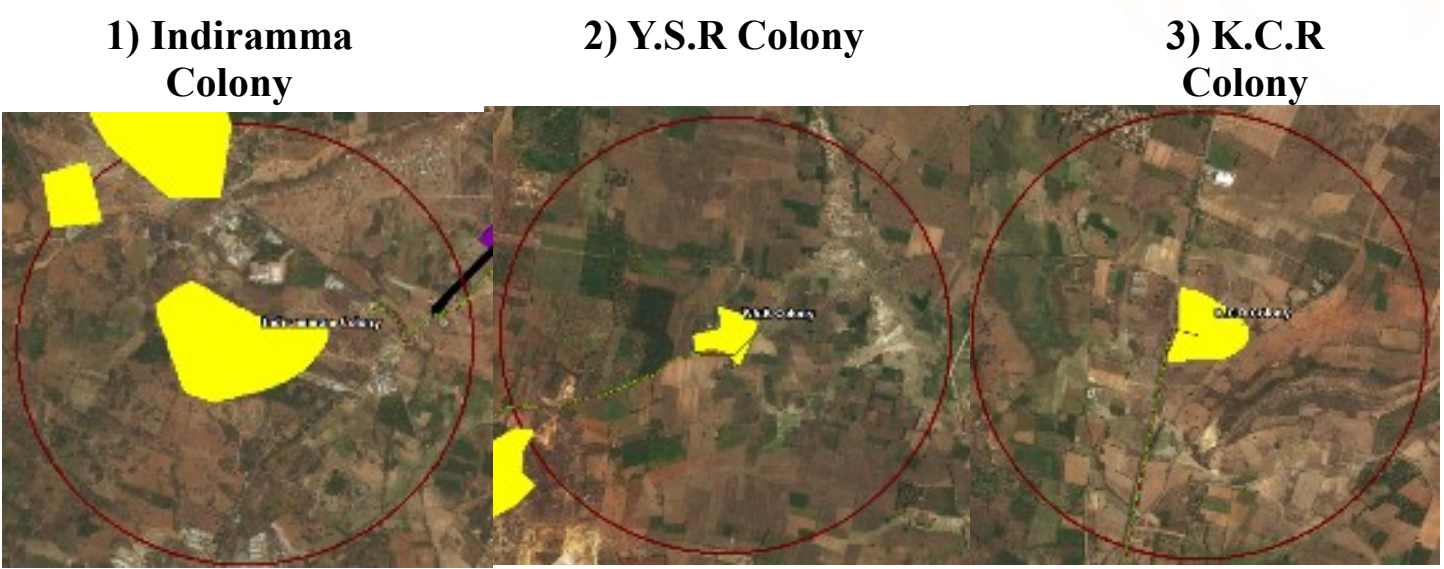


Figure 11: Cause and effect analysis

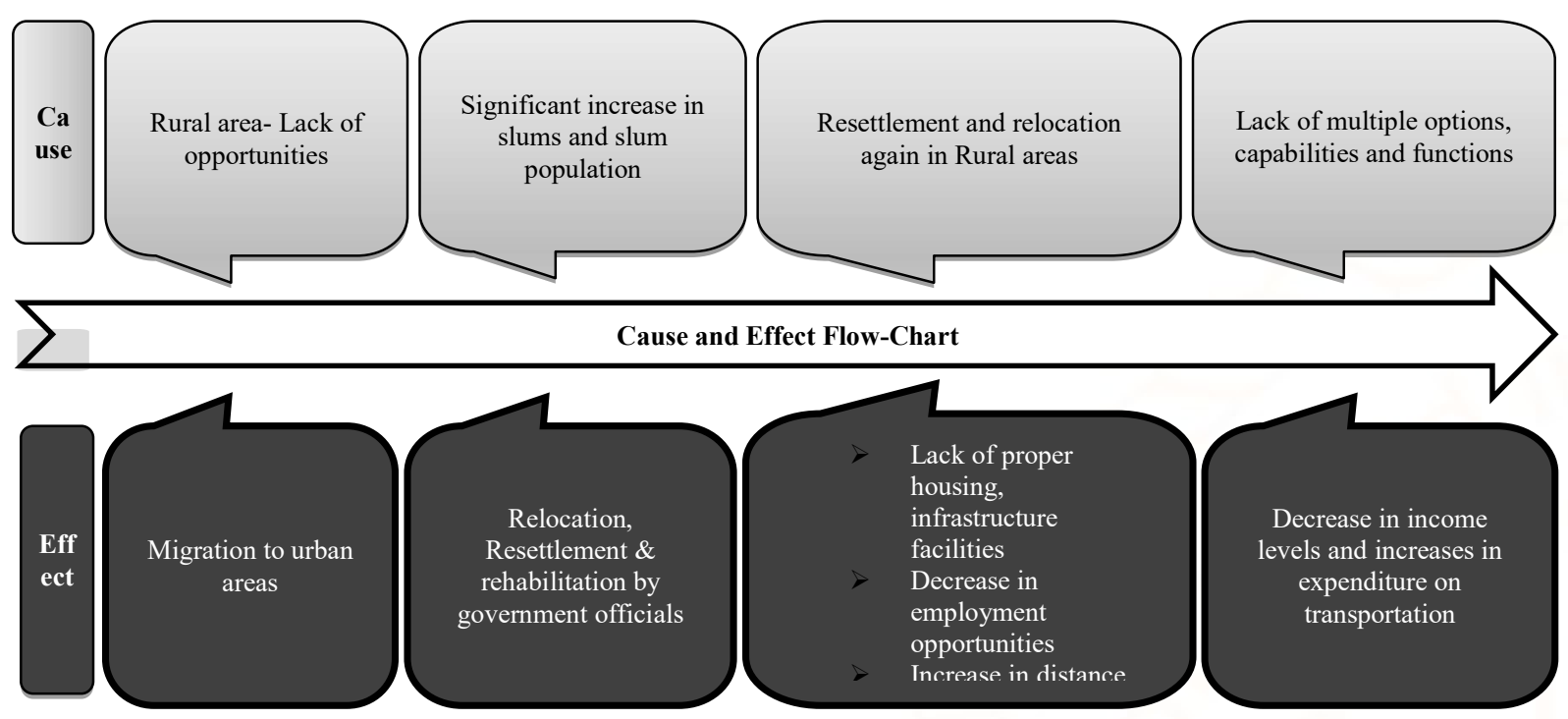

